Fall 2009

\title{
The Decisions of the Corporate Special Litigation Committees: An Empirical Investigation
}

\author{
Minor Myers \\ Brooklyn Law School
}

Follow this and additional works at: https://www.repository.law.indiana.edu/ilj

Part of the Business Organizations Law Commons, and the Securities Law Commons

\section{Recommended Citation}

Myers, Minor (2009) "The Decisions of the Corporate Special Litigation Committees: An Empirical Investigation," Indiana Law Journal: Vol. 84 : Iss. 4 , Article 7.

Available at: https://www.repository.law.indiana.edu/ilj/vol84/iss4/7

This Article is brought to you for free and open access by the Law School Journals at Digital Repository @ Maurer Law. It has been accepted for inclusion in Indiana Law Journal by an authorized editor of Digital Repository @ Maurer Law. For more information, please contact rvaughan@indiana.edu.

\section{$\Psi$}

JEROME HALL LAW LIBRARY

INDIANA UNIVERSITY

Maurer School of Law
Blooming ton 


\title{
The Decisions of the Corporate Special Litigation Committees: An Empirical Investigation
}

\author{
MINOR MYERS*
}

Using an original data set gathered from filings with the U.S. Securities and Exchange Commission, this Article tests the prevailing view in corporate law that special litigation committees invariably decide to dismiss shareholder derivative litigation. It demonstrates that (1) special litigation committees decide to pursue or settle claims much more frequently than heretofore recognized; (2) special litigation committees do not otherwise let defendants off the hook when pursuing or settling claims, in view of the financial recovery to the company in either scenario; (3) most shareholder claims subject to the authority of special litigation committees end up settled, not dismissed; and (4) claims subject to the authority of a special litigation committee are resolved faster than standard derivative claims, indicating that the special litigation committee may serve as a form of alternative dispute resolution. Furthermore, the pattern of financial recoveries to companies suggests that special litigation committees may be more responsive to the merits of shareholder claims than has been recognized before.

The view that special litigation committees behave too predictably has underwritten doubts about the ability of independent and disinterested directors to police conflict of interest transactions generally. The findings presented in this Article show that the prevailing view in the corporate law literature about special litigation committee behavior is an unsound basis for generalizing about how independent and disinterested directors behave.

INTRODUCTION 1310

I. SPECIAL LITIGATION COMMITTEE AUTHORITY AND COMPOSITION. 1312

II. THE CURRENT UNDERSTANDING OF SPECIAL LITIGATION COMMITTEES . 1314

III. THE DATA USED HERE.

IV. RESULTS AND ANALYSIS

A. SUMMARY OF DATA

B. THE FREQUENCY OF SLC APPOINTMENT

C. SLC DECISIONS 1319

D. POSSIBLE EXPLANATIONS WHY THIS FINDING DIFFERS FROM

CONVENTIONAL WISDOM 1320

* Visiting Assistant Professor of Law, Brooklyn Law School. I am grateful to Jennifer Arlen, Lisa Bernstein, Sanjar Bhagat, Dana Brakman Reiser, Edward Cheng, Stephen M. Davidoff, Deborah A. DeMott, James A. Fanto, D. Bruce Johnsen, Lyman Johnson, Roberta Karmel, Alvin Klevorick, Charles Korsmo, John Morley, James Park, Arthur Pinto, Roberta Romano, William K. Wang, Ralph K. Winter, Jr., participants in the 2009 NYU/Penn Conference on Law and Finance, the 2008 Conference on Empirical Legal Studies, the 2008 Conglomerate Junior Scholars Workshop, and faculty workshops at Brooklyn Law School, New York Law School, Roger Williams University School of Law, University of Califomia Hastings College of Law, the University of Iowa College of Law, and the University of Maryland School of Law for very helpful comments; David Goldberg and Rachel Pugliese provided research assistance; and Dean Joan Wexler and the Dean's Research Fund provided research support. 
E. CASE OUTCOMES 1325

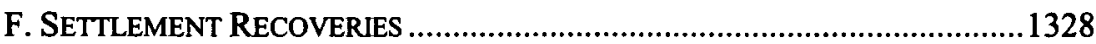

G. HOW THE MERITS RELATE TO SLC DECISIONS...................................1330

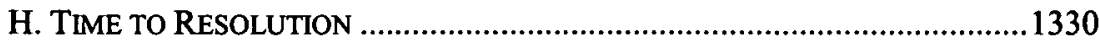

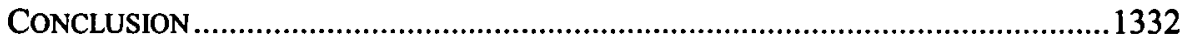

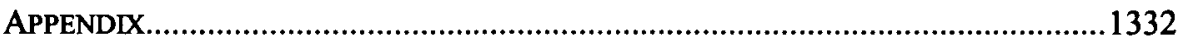

\section{INTRODUCTION}

A special litigation committee (SLC) is a subcommittee of a corporation's board of directors that has the power to intercede in shareholder derivative claims brought against other members of the board. It has the authority to decide whether the derivative claims should be pursued, settled, or dismissed, but its decision is never believed to be in doubt. ${ }^{1}$ Most commentators view the SLC enterprise-the advisors, the investigations, the reports-as little more than a show trial designed to exonerate the accused. ${ }^{2}$

At a symposium on derivative litigation in the mid-1980s, when the SLC was still relatively new, a group of scholars called for empirical investigation into what SLCs actually do, ${ }^{3}$ including the widely held supposition that they recommend dismissal in an overwhelming number of cases. ${ }^{4}$ No such research has appeared in the intervening two decades. As useful as those results would have been then, the answers are even more important now. In corporate law, the role of independent and disinterested directors has only increased over the past generation, especially as a mechanism for controlling conflicts of interest in areas like executive compensation, audit oversight, and buyout negotiations. This growing role for independent directors sits in deep tension with a widespread suspicion that those directors are incapable of negotiating with their colleagues at arm's length. ${ }^{5}$ Although well-known recent work has found the performance of independent directors wanting in this regard, ${ }^{6}$ indictments of

1. William A. Klein \& John C. Coffee, JR., Business ORganization and Finance: LEGAL AND ECONOMIC PRINCIPLES 209 (9th ed. 2004) ("[S]pecial committees almost invariably decide that the derivative action should be dismissed."); see also infra notes 18-19.

2. See infra notes $18-19$.

3. Bryant G. Garth, Ilene H. Nagel \& Sheldon J. Plager, Empirical Research and the Shareholder Derivative Suit: Toward a Better-Informed Debate, 48 LAW \& CONTEMP. PROBS. 137,153 (1985) ("So much of the current literature and case law revolves around this relatively new development that it is important to develop research strategies to test some of the positions that have been taken.").

4. Id. at $155 \mathrm{n} .128$.

5. See infra notes 28-29 and accompanying text. As Professor and former Chancellor William T. Allen once noted, deciding which view is correct-whether disinterested directors are fit to pass judgment on their colleagues - requires an understanding of "how committees of outside directors have in fact tended to act in various settings." William T. Allen, Independent Directors in MBO Transactions: Are They Fact or Fantasy?, 45 BUS. LAw. 2055, 2058-59 (1990) (emphasis in original).

6. E.g., Lucian BebchuK \& Jesse Fried, Pay Without Performance: The Unfulfilled PROMISE OF EXECUTIVE COMPENSATION 4-5 (2004) ("[E]xecutives have had substantial influence over their own pay. Compensation arrangements have often deviated from arm'slength contracting because directors have been influenced by management, sympathetic to 
independent directors' performance are often based on little more than the widespread proposition that SLCs always recommend dismissal. ${ }^{7}$ One commentator summarizes the reasoning in this way: "[I]f purportedly independent directors are likely to favor their fellow directors when the latter are sued, they are equally likely to do so in any conflict of interest situation. ${ }^{, 8}$ SLC behavior thus has implications for the broader issue of whether disinterested and independent directors can patrol corporate conflicts of interest effectively. ${ }^{9}$

Drawing on an original data set of SLC decisions from 1993 to 2006, this Article tests the hypothesis that corporate SLCs always decide to dismiss the shareholder derivative litigation they control. The data indicate that SLCs do not uniformly decide to dismiss derivative litigation. They sought some form of formal relief much more frequently than heretofore recognized: approximately forty percent of the time, SLCs pursued or settled claims against one or more defendants.

A broader claim about SLC behavior-that, even if they do not dismiss claims, they may nevertheless take it easy on defendants by failing to pursue claims diligently or by settling claims for nothing-also finds no support in the data. When SLCs decided to pursue claims or settle them, the company received meaningful financial recoveries. SLCs thus do not appear to be in the business of letting defendants off the hook, either by dismissing claims or by pressing them with no zeal.

The SLC decision is not the final procedural development in cases, and a majority of all cases subject to their review eventually end up settled, not dismissed. Dismissal is not even the most common outcome when the SLC decides to seek dismissal of the claims. What has been viewed as the great engine for dismissing shareholder derivative cases actually ends up resulting in mostly settlements.

The pattern of recoveries in settlement suggests that SLCs may be more sensitive to the merits of shareholder claims than has been recognized before. Company recoveries were large in the median instance when SLCs decided to pursue claims, modest when they decided to settle claims, and zero when they decided to dismiss claims. To the extent that settlement values correlate with merit, SLCs pursue strong claims, dismiss weak ones, and settle close ones.

The data also indicate one important reason why a company might use an SLC: cases in which an SLC is appointed are resolved much faster than derivative cases generally. This suggests SLCs may function as a form of alternative dispute resolution.

The data used here provide a first glimpse in a generation into the decisions SLCs make, but they have some notable limitations. Because these data are drawn from securities filings, the amount of detail is limited by what is presented in the filings themselves. Important information not reliably disclosed includes: the identity and holdings of the plaintiff, the defendants, and the committee members; the conduct

executives, insufficiently motivated to bargain over compensation, or simply ineffectual in overseeing compensation.").

7. See, e.g., StePhen M. BAINBRIDGe, Corporation LAW AND ECONOMICS 227 (2002) ("Most of the learning on . . . structural bias ... arises out of the use of special litigation committees to terminate shareholder derivative actions against officers or directors.").

8. Id. at 228.

9. Kenneth B. Davis, Jr., Structural Bias, Special Litigation Committees, and the Vagaries of Director Independence, 90 IowA L. REv. 1305, 1307 (2005) ("[T] he law and many of the procedures that developed in the SLC context have direct implications for the larger corporate governance reform now underway."). 
giving rise to the derivative claim, whether the plaintiff made a prior demand upon the board; and the source of funds for any settlement. Further, as noted in the Appendix, the filings do not usually present a fine-grained description of how the SLC resolved the claims in any particular case. Thus, the findings here represent just a preliminary picture of contemporary SLC behavior, and future research drawing upon other sources like court filings may be able to present a more complete picture.

Part I of this Article describes SLCs, Part II presents the current understanding of what SLCs do, Part III describes the data set used in this Article, and Part IV presents the data and analyzes it.

\section{SPECIAL LITIGATION COMMITTEE AUTHORITY AND COMPOSITION}

The authority for an SLC to control derivative claims asserted by a shareholder grows out of the board's authority over all of the corporation's legal claims.

The board's plenary managerial authority includes the power to control legal claims that a manager has breached her fiduciary duty to the corporation. ${ }^{10}$ That authority, however, can be disabled when the directors who must ultimately decide whether to bring a lawsuit are themselves defendants or are otherwise implicated in the alleged wrongdoing. In such circumstances, a shareholder may stand in the shoes of the corporation and assert a claim on its behalf in a shareholder derivative suit. ${ }^{11}$

The SLC mechanism emerged in the 1970s as a way for the board to reassert its authority over the derivative claim, even if a majority of the board is implicated by the allegations. The board creates an ad hoc committee of directors who have no interest in the outcome of the litigation and are independent of those who have such an interest. ${ }^{12}$ In the eyes of the law, this mechanism eliminates the conflict that necessitated the derivative suit in the first place.

10. E.g., Del. CODE ANN. tit. 8, $\S 141$ (a) (2001) ("The business and affairs of every corporation organized under this chapter shall be managed by or under the direction of a board of directors, except as may be otherwise provided in this chapter or in its certificate of incorporation."); see also Auerbach v. Bennett, 393 N.E.2d 994, 1000 (N.Y. 1979) ("Derivative claims against corporate directors belong to the corporation itself."); Michael P. Dooley \& E. Norman Veasey, The Role of the Board in Derivative Litigation: Delaware Law and the Current ALI Proposals Compared, 44 Bus. LAW. 503, 504 (1989) ("In derivative actions the claims belong to the corporation, not to the complaining stockholder.").

11. See generally Levine v. Smith, No. 8833, 1987 Del. Ch. LEXIS 524, at *6 (Del. Ch. Dec. 22, 1987) (noting that the shareholder plaintiff assumes "the legal managerial power to maintain a derivative action to enforce the corporation's claim"); DEBORAH A. DEMOTT, SHAREHOLder DeRIVATIVE ACtIONS: LAW AND PRACTICE (2003 \& Supp. 2009).

12. Practitioners emphasize the importance of selecting persons who are disinterested and independent. SLC members are often new appointees to the board or are sometimes outside directors already on the board. See also In re Oracle Corp. Derivative Litig., 824 A.2d 917 (Del. Ch. 2003) (finding a lack of independence based on mutual associations with Stanford University); see generally RALPH C. FERRARA, KEVIN T. ABIKOFF \& LAURA LEEDY GANSLER, SHAREHOLDER DERIVATIVE LITIGATION: BESIEGING THE BOARD § 8.10 (SUpp. 2008); 1 ROGER J.

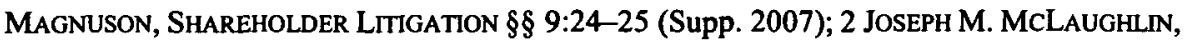
MCLAughuIN on Class ACTIONS § 9:16 (2006); Robert K. Payson, Michael D. Goldman \& Gregory A. Inskip, After Maldonado-The Role of the Special Litigation Committee in the Investigation and Dismissal of Derivative Suits, 37 Bus. LAw. 1199, 1202-03 (1982). 
An SLC typically hires outside counsel, investigates the allegations in the derivative complaint, and consults with plaintiff's counsel to hear the plaintiff's grievances. ${ }^{13}$ The SLC weighs not only the legal merits of a claim but also other factors like the injury suffered by the corporation, the defendants' knowledge and motivation, the direct expenses of litigation, and the indirect costs of litigation, including potential waste of management time and adverse public relations. In this sense, the SLC evaluates the claims the same way the board evaluates any other business decision. After its investigation, the SLC decides whether to pursue the claims, settle them, or seek their dismissal. ${ }^{14}$ If the committee decides to settle the claims or pursue them, it may proceed with or without the cooperation of the plaintiff's attorney. ${ }^{15}$ If the SLC concludes that pressing the claims is not in the best interests of the corporation, it will generally produce a written report supporting its conclusion and will move on behalf of the corporation to dismiss the claims.

Although a practice of comparatively recent provenance, using an SLC of disinterested directors to neutralize the conflict between the corporation and the director-defendants fits neatly into the general corporate law approach to decisions where directors are on both sides. Henry Hansmann and Reinier Kraakman have termed this legal strategy "trusteeship," noting that it "seeks to eliminate conflicts of interest ex ante to ensure that 'bad' behavior by an agent will not be rewarded" and assumes that without financial incentives the trustees (here, disinterested directors) "will respond to the 'low-powered' incentives of conscience, pride, and reputation, and are thus more likely to manage in the interests of their principals." ${ }^{16}$ When directors are on both sides of a transaction but a board's disinterested directors approve it, a court will apply only business judgment review. ${ }^{17}$ Standing board compensation committees

13. See FERRARA ET AL., supra note $12, \S 8.10 ; 1$ MAGNUSON, supra note $12, \S \S 9: 24-25 ; 2$ MCLAUGHLIN, supra note $12, \S 9: 16$.

14. 2 MCLAUGHLIN, supra note $12, \S 9: 16$ (noting that SLCs ordinarily issue a report with "the conclusion of the SLC with respect to the claim and a recommended course of action, i.e., whether the claim should be prosecuted, dismissed or settled, subject to judicial approval") (emphasis in original).

15. On pursuit, see R. Franklin Balotti \& Jesse A. Finkelstein, The Delaware Law of CORPORATIONS AND BUSINESS ORGANIZATIONS $\S 13.17$ (2007) ("It appears that if a special litigation committee determines that the best interests of the corporation would be served by further litigation of derivative claims, the corporation may either take control of the litigation itself or allow the stockholder-plaintiff to pursue the claims on behalf of the corporation."). On settlement, see Carlton Invs. v. TLC Beatrice Int'l Holdings, Inc., No. 13950, 1997 WL 305829 (Del. Ch. May 30, 1997) (approving an SLC-negotiated settlement against the wishes of the shareholder-plaintiff).

16. Henry Hansmann \& Reinier Kraakman, Agency Problems and Legal Strategies, in THE ANATOMY OF CORPORATE LAW 21, 27 (Reinier Kraakman, Paul Davies, Henry Hansmann, Gerard Hertig, Klaus Hopt, Hideki Kanda \& Edward Rock eds., 2004).

17. See Auerbach v. Bennett, 393 N.E. 2d 994, 1001 (N.Y. 1979) (fitting SLC practice into "the general policy that when individual members of a board of directors prove to have personal interests which may conflict with the interests of the corporation, such interested directors must be excluded while the remaining members of the board proceed to consideration and action."); see also DEL. CODE ANN. tit. 8, § 144(a)(1) (2001) (insulating interested transactions from challenge so long as a majority of disinterested directors approves the transaction); KLEIN \& COFFEE, supra note 1, at 161 ("A typical statute creates a 'safe harbor' rule under which a 
and ad hoc committees to negotiate control transactions with inside bidders are common examples of this strategy at work.

\section{The CuRRENT UNDERSTANDING OF SPECIAL LITIGATION COMMITTEES}

Academic legal commentators are nearly unanimous in the belief that SLCs always decide to dismiss derivative litigation. ${ }^{18}$ Practitioners concur. ${ }^{19}$

In spite of this consensus, there is little evidence to support it. Much of the current understanding of what SLCs do can be traced back to an influential 1982 survey by Professor James D. Cox. ${ }^{20} \mathrm{He}$ identified around twenty reported cases involving SLC decisions and found that in all but one of them the SLC at issue had concluded that the claims were not in the corporation's best interest. ${ }^{21}$ Other examinations of reported

director's conflict does not render the transaction voidable if the transaction was ... approved by disinterested directors after full disclosure as to the conflict ...."). But see infra notes 29-34 (describing states that apply more scrutiny than business judgment or do not recognize SLC authority at all).

18. E.g., ROBERT CHARLES CLARK, CORPORATE LAW $§ 15.2 .3$ (1986) (describing that "after a suitable display of investigative activity and collective deliberation, [a typical SLC] would produce a report that concluded, unsurprisingly, that the committee thought it was in the corporation's 'best interest' not to proceed with the lawsuit"); FrankLIN A. GEvURTZ, CORPORATION LAW 412 (2000) ("Special litigation committees, almost without exception, have concluded that derivative suits which the committees looked into were not in the corporation's best interest."); KLEIN \& COFFEE, supra note 1, at 209 ("special committees almost invariably decide that the derivative action should be dismissed"); 9 Louis Loss \& Joel SELIGMaN, SECURITIES REGULATION $\S 11(\mathrm{C})(4)(\mathrm{b})$ n.340 (3d ed. 2004) ("Special litigation committees almost invariably have recommended that derivative actions should not be continued."); Jonathan R. Macey, Corporate Governance: Promises KePt, Promises Broken 65-66 (2008) ("SLCs uniformly recommend that derivative lawsuits brought by outside shareholders be dismissed."); Daniel J. Morrissey, The Path of Corporate Law: Of Options Backdating, Derivative Suits, and the Business Judgment Rule, 86 OR. L. REV.973, 1003 (2007) (an SLC "almost always recommend[s] dismissal"); Charles W. Murdock, Corporate Governance-The Role of Special Litigation Committees, 68 WASH. L. REV. 79, 84 (1993) ("[i]nvariably the committee moves to dismiss the litigation"); Robert B. Thompson \& Randall S. Thomas, The Public and Private Faces of Derivative Lawsuits, 57 VAND. L. REV. 1747, 1791 n. 147 (2004) (noting that "the limited data that has been collected on [SLC behavior] supports the view that the appointment of a special litigation committee almost always leads to dismissal of the case").

19. E.g., FERRARA ET AL., supra note $12, \S 8.06$ ("[I]t is well-established that special litigation committees have sided with the defendants in an overwhelming number of cases in which they have been employed."); 1 MAGNUSON, supra note12, $\$ 9: 23$ ("If the 'disinterested' special litigation committee is not impressed by the plaintiff's lawsuit (and they never are), the lawsuit is over. . . . Special litigation committees always recommend dismissal." (citations omitted)); 2 MCLAUGHLIN, supra note $12, \S 9: 16$ ("The experience in the great majority of cases has been that the SLC issues a report recommending that the demanded litigation is not in the best interests of the corporation.").

20. James D. Cox, Searching for the Corporation's Voice in Derivative Suit Litigation: $A$ Critique of Zapata and the ALI Project, 1982 DUKE L.J. 959.

21. Id. at $963 \mathrm{nn} .13 \& 14$ ("[A]lthough there have been more than a score of special litigation committee cases to date, in all but one the committee concluded that the suit in question was not in the corporation's best interest."). 
cases around the same time added force to Professor Cox's conclusions. ${ }^{22}$ Professor Cox updated his research to reflect decisions reported through 1988, and that revised research revealed forty-four decisions involving an SLC and only one instance where an SLC recommended pursuing the underlying claims. ${ }^{23}$ These 1980 s surveys appear to be the entirety of the evidence on what SLCs do. ${ }^{24}$ Anecdotal reports have been said to support the conclusion of these studies, ${ }^{25}$ and contrary SLC decisions in reported cases are viewed as outliers. ${ }^{26}$

22. E.g., Richard C. Brown, Shareholder Derivative Litigation and the Special Litigation Committee, 43 U. PITT. L. REv. 601, 620-21 (1982) (collecting reported cases in support of the conclusion that "[s]pecial litigation committees, after completing their investigations, have so far always determined that the derivative action was not in the best interests of the corporation and have voted to terminate the suit"); George W. Dent, Jr., The Power of Directors to Terminate Shareholder Litigation: The Death of the Derivative Suit?, 75 Nw. U. L. REV. 96, $109 \&$ n.70 (1980) (collecting reported cases on demand in support of the conclusion that in the SLC context "almost invariably, the directors charged with the decision decide to oppose the suit").

23. Thompson \& Thomas, supra note 18 , at $1791 \mathrm{n} .147$ (noting private correspondence from Professor Cox to the authors).

24. AM. LAW INST., PRINCIPLES OF CORPORATE GOVERnANCE: ANALYSIS AND RECOMMENDATIONS 161 (Tentative Draft No. 8, 1988) ("Efforts to calculate the outcome of litigation committee determinations have reported that the committee, once formed, has almost invariably recommended dismissal of the action against all defendants." (citing Cox supra note 20, at 959)). Many commentators limit their claims about SLC behavior to what the available evidence shows. BAINBRIDGE, supra note 7, at 399-400 ("The legitimacy of [the Delaware Supreme Court's 'there but for the grace of God go I' concern] is supported by the fact that in only one of the first 20 reported SLC decisions did the committee determine that the suit should proceed."); ROBERT W. Hamilton \& Jonathan R. Macey, Cases and Materials on CORPORATIONS 734 (10th ed. 2007) (suggesting that in "virtually every case" SLCs decide only not to pursue); ARTHUR R. PINTO \& DOUglas M. Branson, UNDERSTANDING CORPORATE LAW 465 (2d ed. 2004) (noting that "no SLC has ever recommended that derivative litigation continue against sitting officers, as opposed to former directors or senior executive officers."); Julian Velasco, Structural Bias and the Need for Substantive Review, 82 WASH. U. L.Q. 821, 857 (2004) (noting that disinterested directors "naturally are averse to derivative litigation" and "consistently reject demands and otherwise seek dismissal of derivative actions").

25. GEVURTZ, supra note 18, at 412 n.106 (noting that "no anecdotal reports of favorable committee recommendations regarding a derivative suit and no reports of any case in which the corporation took over and prosecuted a suit against the company's directors based upon a committee's decision").

26. Id. (noting that the only "exceptions to the negative evaluation of derivative suits by special litigation committees occurred in a couple of cases in which the committees recommended dismissing the actions against the corporations' directors, but either settling or continuing the actions against several lower level present or former corporate officials." (citing Joy v. North, 692 F.2d 880 (2d Cir. 1982); In re Cont'l Ill. Sec. Litig., 572 F. Supp. 928 (N.D. Ill. 1983)). Professor Cox's treatise (with Professor Thomas Lee Hazen) says that "committees have generally concluded that continuation of the suit would not promote the best interests of the corporation. Occasionally, a committee will propose a settlement of the action to the derivative suit court." JAMES D. COX \& THOMAS LEE HAZEN, COX \& HAZEN ON CORPORATIONS 939 (2d ed. 2003). 
Some commentators have suggested that the lopsided SLC behavior can be attributed to the lack of merit in derivative claims generally, ${ }^{27}$ but the more prevalent explanation is that directors on an SLC are naturally inclined to favor their imperiled colleagues. Various accounts of this favoritism have been lumped together under the term "structural bias.",28

Commentators have suggested that in view of structural bias courts should apply enhanced scrutiny when an SLC seeks dismissal of shareholder claims. Some of the leading court decisions reviewing the work of SLCs have adopted that argument. ${ }^{29}$ The Delaware Supreme Court, noting the potential for "subconscious abuse" and wondering whether SLC members might not be afflicted with a feeling of "' there but for the grace of God go I," 30 established a two-step test where the court reviewing an SLC motion to dismiss first scrutinizes the independence of SLC members but also has the discretion to assess the merits of the SLC's decision using its own independent business judgment. ${ }^{31}$ The Iowa Supreme Court went further, finding the threat of structural bias so great that it refused entirely to defer to SLC decisions. ${ }^{32}$

Other courts have been less receptive to the structural bias argument and review an SLC decision like any other business decision by disinterested directors. In New York, for example, a court's inquiry is limited to the independence of the SLC's members and the adequacy of its investigation, and an SLC's "substantive evaluation of the problems posed and its judgment in their resolution are beyond [a court's] reach." 33 Courts in California, Colorado, and Minnesota, along with the legislature in Indiana, have followed New York. ${ }^{34}$

\section{THE DATA USED HERE}

The data on SLCs used here were hand-collected from registration statements, periodic financial reports, proxy solicitations, and other documents filed with the U.S. Securities and Exchange Commission (SEC). ${ }^{35}$ Although the SEC's disclosure

27. HAMILTON \& MACEY, supra note 24, at 734 (suggesting that SLC decisions can "be explained on the basis that virtually all derivative litigation filed today is without merit" (citations omitted)).

28. See Davis, supra note 9, at 1309; Velasco, supra note 24, at 824.

29. See In re Oracle Corp. Derivative Litig., 824 A.2d 917, 938 (Del. Ch. 2003) ("[C]orporate directors are generally the sort of people deeply enmeshed in social institutions. Such institutions have norms, expectations that, explicitly and implicitly, influence and channel the behavior of those who participate in their operation."). Many state courts have not yet considered the authority of corporate SLCs.

30. Zapata Corp. v. Maldonado, 430 A.2d 779, 787 (Del. 1981).

31. Id. at 788-89.

32. Miller v. Register \& Tribune Syndicate, Inc., 336 N.W.2d 709, 718 (Iowa 1983) (seeking to "prevent the potential for structural bias in some cases by effectively limiting the powers of such directors in all cases").

33. Auerbach v. Bennett, 393 N.E.2d 994, 1000-02 (N.Y. 1979).

34. See IND. CoDE § 23-1-32-4(c) (2005); Desaigoudar v. Meyercord, 133 Cal. Rptr. 2d 408, 418-19 (Cal. Ct. App. 2003); Hirsch v. Jones Intercable, Inc., 984 P.2d 629, 637-38 (Colo. 1999); Black v. NuAire, Inc., 426 N.W.2d 203, 209-10 (Minn. Ct. App. 1988).

35. The data collected here thus include only organizations that comply with SEC disclosure requirements. Generally, this means publicly traded companies, but as Robert Bartlett 
requirements are not clear on the matter, the actual disclosure practice of SEC filers demonstrates that companies are in the habit of disclosing information about derivative litigation and SLCs in their filings. SLCs were identified by running word searches through the SEC's EDGAR (Electronic Data Gathering, Analysis, and Retrieval system) database during the ten-year period from 1995 to $2004 .^{36}$ Each filing that appeared in the search results was reviewed to determine whether the registrant (or a related company) had formed an SLC. For purposes of this study, an SLC is a board committee with authority over pending derivative litigation. The process of collecting the data is described in greater detail in the Appendix.

One important source of possible bias in the data is worthy of note. Disclosure practices vary from one SEC filer to another, and in view of the ambiguous disclosure requirements, ${ }^{37}$ it is possible that those companies that disclose information about derivative litigation and SLCs will be companies that generally resolve ambiguous disclosure provisions in favor of greater disclosure. Directors on an SLC at such companies, given their commitment to transparency, might be more inclined to hold their colleagues accountable, deciding to dismiss derivative claims less often. When pursuing or settling claims, they might negotiate a higher monetary recovery for the company and a lower payment to the plaintiff's attorney. This could bias the data in favor of results that appear beneficial to shareholders, making SLCs look especially conscientious. The data would include a disproportionately small number of (1) SLCs deciding to dismiss meritorious claims or (2) SLCs deciding to settle (or possibly pursue) nonmeritorious claims. However, even if the nondisclosed information is different from the disclosed information in important ways, the high proportion of SLCs mentioned in reported cases that also disclosed the relevant information in SEC filings (eighty-four percent) offers a degree of confidence that most of the information is disclosed. ${ }^{38}$

\section{RESULTS AND ANALYSIS}

\section{A. Summary of Data}

The data include 106 SLCs formed to manage derivative litigation. These were formed by 103 different organizations. Ninety-eight of those organizations were corporations, three were mutual funds, one was a limited partnership, and one was a real estate investment trust. Approximately half of the organizations forming SLCs were organized in Delaware.

The earliest SLC decision is from 1993, and the latest is from 2006. The number of decisions per year is shown in Figure 1.

has shown, some organizations with no publicly owned equity nevertheless continue to comply with SEC disclosure obligations. Robert P. Bartlett, III, Going Private but Staying Public: Reexamining the Effect of Sarbanes-Oxley on Firms' Going-Private Decisions, 76 U. CHI. L. REv. (forthcoming 2009).

36. The EDGAR database is the SEC's repository for electronic company filings. See U.S. Sec. and Exch. Comm.: Filings \& Forms, http://www.sec.gov/edgar.shtml. Some filings during that period describe SLC behavior from before that period and after it, and that data has been included in this study.

37. For information on the ambiguity of the disclosure requirements, see Appendix.

38. See Appendix for more on the calculation of the eighty-four percent figure. 
Figure 1. Special Litigation Committee Decisions by Year

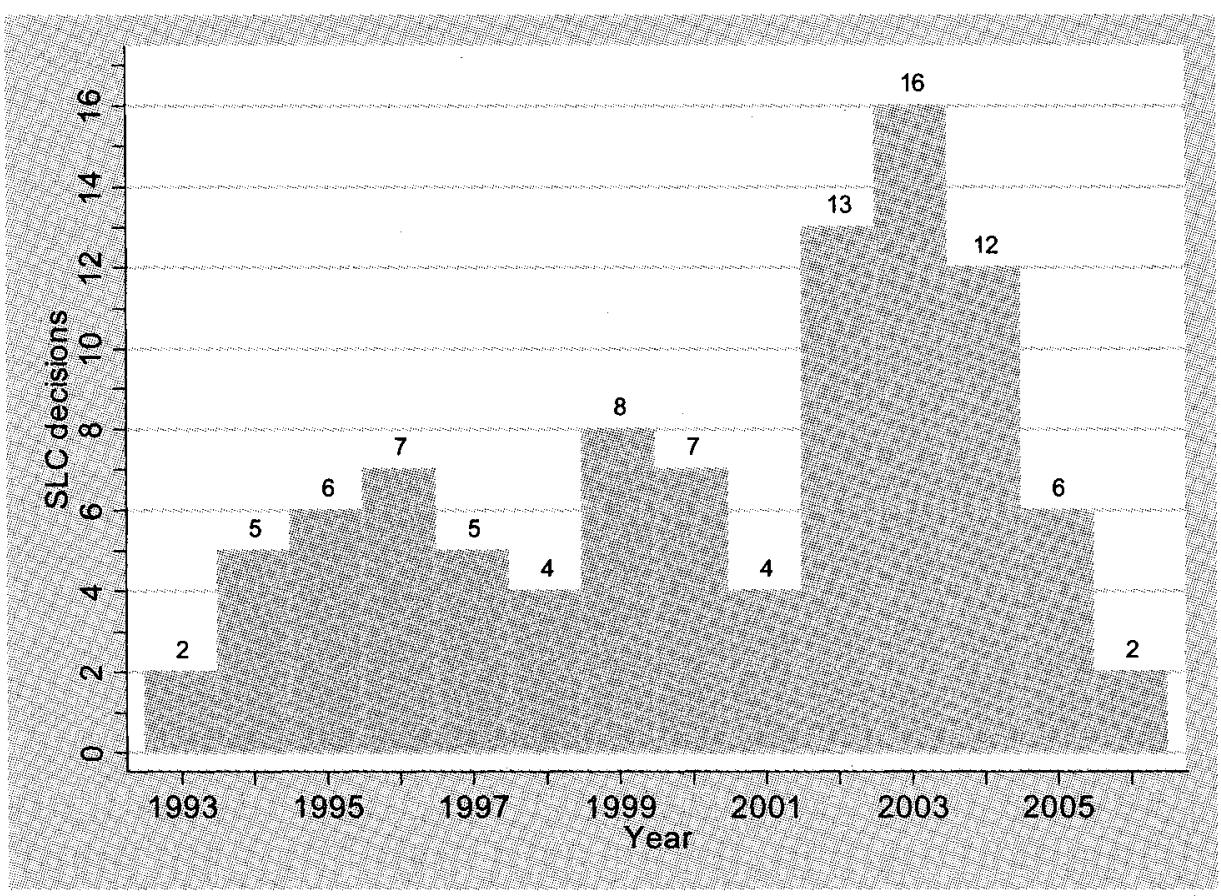

Approximately ten percent of the SLCs were formed by organizations that did not have a public market for their equity securities. ${ }^{39}$ The average time between the first filing of a derivative claim and the SLC's decision was approximately 1.5 years.

\section{B. The Frequency of SLC Appointment}

Because this study starts with a population of SLCs, not derivative lawsuits, it is difficult to say anything with precision about trends in SLC use or about how frequently SLCs are appointed. ${ }^{40}$

39. An organization may not be publicly owned but nevertheless comply with the SEC's disclosure obligations because the organization has a high-yield note indenture that requires continued disclosure or because the equity holders may value the firm's commitment to compliance with disclosure obligations. Bartlett, supra note 35 .

40. All domestic registrants became subject to the electronic filing requirements in May 1996. Charles N. Charnas \& D. Craig Nordlund, Introduction to Operational EDGAR: An Outline for Electronic Filing with the SEC, in Preparation OF ANNUAL DISCLOSURE DocumenTS 1997, at 281, 286 (PLI Corp. Law \& Practice Course Handbook Series No. 969, 1997) ("This phase-in was completed by May 6, 1996, and all registrants should currently be using EDGAR for their filings."). SLC decisions in the data from the periods 1993-94 and 2005-06 do not represent all SLC activity then because those decisions are included here only if they were mentioned in filings between 1995 and 2004. Within the 1997-2004 period, the data should include all SLC decisions. Although the number of SLC decisions increased threefold from 2001 to 2002, it is impossible to say whether this represents a change up or down in the number of litigation committee decisions relative to the number of derivative filings. 
A study by Professors Thompson and Thomas can help provide a rough estimate of the frequency with which SLCs are appointed in derivative cases. ${ }^{41}$ They studied all corporate litigation in the Delaware chancery courts during 1999 and 2000 and found 108 derivative complaints filed against public companies during those two years. Of those, they found two cases in which an SLC was used. ${ }^{42}$ Their data suggest that SLCs are appointed in approximately $1.9 \%$ (two out of 108 ) of complaints against public companies filed in the Delaware Courts of Chancery. The data here, however, allow for a different calculation, because they show that derivative litigation against Delaware corporations sometimes proceeds completely outside of Delaware. ${ }^{43}$ Included in the data here are six SLCs created to manage derivative cases that were filed against publicly traded organizations incorporated in Delaware during 1999 and 2000. However, in only four of those instances did disclosures indicate that a complaint had been filed in the Delaware Court of Chancery; two were litigated entirely elsewhere. Using the same Thompson and Thomas denominator, an SLC was thus appointed by Delaware companies with a complaint filed in Delaware in approximately $3.7 \%$ of cases. Both calculations demonstrate that the appointment of an SLC was an infrequent occurrence for claims filed in 1999 and 2000.

\section{SLC Decisions}

For ninety-seven of the SLCs identified, the committee's decision could be determined from the filings. ${ }^{44}$ The decisions fit into the three categories: dismiss, pursue, or settle. The following rules were used to categorize decisions: If the SLC determined to dismiss all claims against all defendants, the decision was to dismiss. If the SLC determined to pursue any of the claims against any defendant, the decision was to pursue. If any of the claims are settled and none are pursued against any defendant, the decision was to settle. The SLC decisions, by category, are shown in Table 1.

41. Thompson \& Thomas, supra note 18.

42. One of the SLCs in their study recommended dismissal, and this SLC is in this data set. Id. at $1781 \mathrm{n} .121$ (citing Kindt v. Lund, No. 17751-NC, 2003 Del. Ch. LEXIS 62 (Del. Ch. May 30, 2003) (granting NuSkin Enterprises's motion to dismiss based on report and recommendation of SLC)). The other SLC was formed by a company not in the EDGAR database and is not in this data; its appointment "led to a settlement." Id. at 1781.

43. In this study, more often than not, when an SLC was created to manage allegations against a Delaware corporation, no complaint was filed in Delaware. In only twenty out of fortythree such instances was a complaint, even a nonlead complaint, filed in Delaware. One important caveat here is that disclosure documents might not always list all jurisdictions in which a claim has been filed.

44. For the other nine SLCs, a decision could not be determined because the filer entered bankruptcy and took care of its derivative claims in reorganization; it ceased filing for unknown reasons; it was acquired; etc. There were no evident unique characteristics of these nine SLCs. 
Table 1. Decisions of Special Litigation Committees by Category

\begin{tabular}{|l|c|}
\hline \multicolumn{1}{|c|}{ Category of SLC Decision } & Number of SLCs (n=97) \\
\hline Dismiss & $58(60 \%)$ \\
\hline Settle & $29(30 \%)$ \\
\hline Pursue & $10(10 \%)$ \\
\hline
\end{tabular}

In three instances where an SLC determined to dismiss derivative litigation, the company had already sought relief from one or more of the defendants named in the derivative litigation. If those decisions were not coded as ones to dismiss, SLC decisions to dismiss would amount to fifty-six percent of all SLC decisions.

Based on the rules used to categorize decisions, an outcome categorized here as a decision to settle might have been a settlement with only one defendant of only one claim, where all remaining (and possibly more potent) claims might have been dismissed. While categorizing the decision as one to settle sacrifices some information, it nevertheless conveys the most important aspect of that SLC decision, in view of the prevailing understanding of SLC behavior, by reflecting any outcome that is not a decision to dismiss. That only some claims against some defendants are pursued or settled should hardly be surprising. A plaintiff might not know the identities of the actual wrongdoers without the benefit of discovery and thus might name all possible defendants. To be sure, in settling claims an SLC might have done just enough to pass the straight-face test, ${ }^{45}$ maybe striking a feeble settlement with only the most egregious offenders. However, the settlement data described below suggest otherwise; decisions to pursue or settle claims generate meaningful financial recoveries for the company.

\section{Possible Explanations Why this Finding Differs from Conventional Wisdom}

As the data show, SLCs do not invariably move to dismiss derivative litigation. ${ }^{46}$ Over forty percent of the time the SLC either settled or pursued one or more claims against one or more defendants.

45. See Joy v. North, 692 F.2d 880 (2d Cir. 1982) (denying SLC motion to dismiss against twenty-three defendants after SLC agreed to settle with seven other defendants).

46. Dividing the SLCs into publicly traded and nonpublicly traded organizations does not make much difference. The decisions of SLCs by category and by ownership are as follows:

Footnote Table 1. SLC Decisions by Public or Nonpublic Equity

\begin{tabular}{|l|c|c|c|}
\hline Category of SLC Decision & $\begin{array}{c}\text { Publicly Traded } \\
(\mathrm{n}=86)\end{array}$ & $\begin{array}{c}\text { Not Publicly Traded } \\
(\mathrm{n}=9)\end{array}$ & Total (n=97) \\
\hline Dismiss & $51(59 \%)$ & $5(55 \%)$ & $58(60 \%)$ \\
\hline Settle & $27(31 \%)$ & $2(22 \%)$ & $29(30 \%)$ \\
\hline Pursue & $8(9 \%)$ & $2(22 \%)$ & $10(10 \%)$ \\
\hline
\end{tabular}

Two entities could not be classified as publicly traded or not. See supra note 39 for an explanation of why firms with no publicly traded equity appear in the data. SLCs in publicly 
Two possible explanations for why this finding differs from the traditional understanding of SLC decisions are (1) changes in SLC behavior over time and (2) bias in the data used in prior studies.

\section{SLC Decisions over Time}

All prior studies of SLC decisions date from the 1980s. In the intervening years, perhaps SLC behavior has evolved, possibly as a result of the diminishing role of insiders on corporate boards, greater public scrutiny of corporate behavior, or other factors. $^{47}$

The EDGAR database does not permit investigation of SLC decisions from the 1970 s or 1980 s because it started only in the early 1990 s (the earliest SLC behavior in the data set dates from 1993). Table 2 shows SLC decisions from EDGAR tabulated by the year in which they were made.

Table 2. Decisions Per Year by Category of Decision

\begin{tabular}{|c|c|c|c|c|c|c|c|c|c|c|c|c|c|c|}
\hline Year & 宗 & ळ & 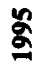 & \& & $\bar{g}$ & 号 & & ఫ్లి & ర్ల్ & ఫ్ల్ల & 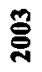 & 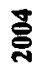 & క్సે & ర్ల \\
\hline Settle & 0 & 2 & 2 & 2 & 0 & 1 & 2 & 4 & 0 & 3 & 5 & 4 & 2 & 2 \\
\hline Pursue & 0 & 1 & 2 & 1 & 0 & 0 & 0 & 0 & 1 & 1 & 1 & 2 & 1 & 0 \\
\hline Dismiss & 2 & 2 & 2 & 4 & 5 & 3 & 6 & 3 & 3 & 9 & 10 & 6 & 3 & 0 \\
\hline Total & 2 & 5 & 6 & 7 & 5 & 4 & 8 & 7 & 4 & 13 & 16 & 12 & 6 & 2 \\
\hline
\end{tabular}

traded firms and non-publicly traded firms decided to dismiss claims at roughly the same rate. When not dismissing claims, publicly traded firms settled more regularly than did non-publicly traded firms. These differences are not statistically significant $(p=0.464)$.

47. Professor Deborah DeMott suggested just this in a recent update to her treatise on derivative litigation. DEMoTT, supra note $11, \S 5: 18$ ("More recent examples suggest that litigation committees may recommend that claims be pursued following either changes in control of the corporation or abuses at startling levels of excess and abuse."). 
Figure 2 shows the percentage of each category of decision by year.

Figure 2. Percentage of Decision Category by Year

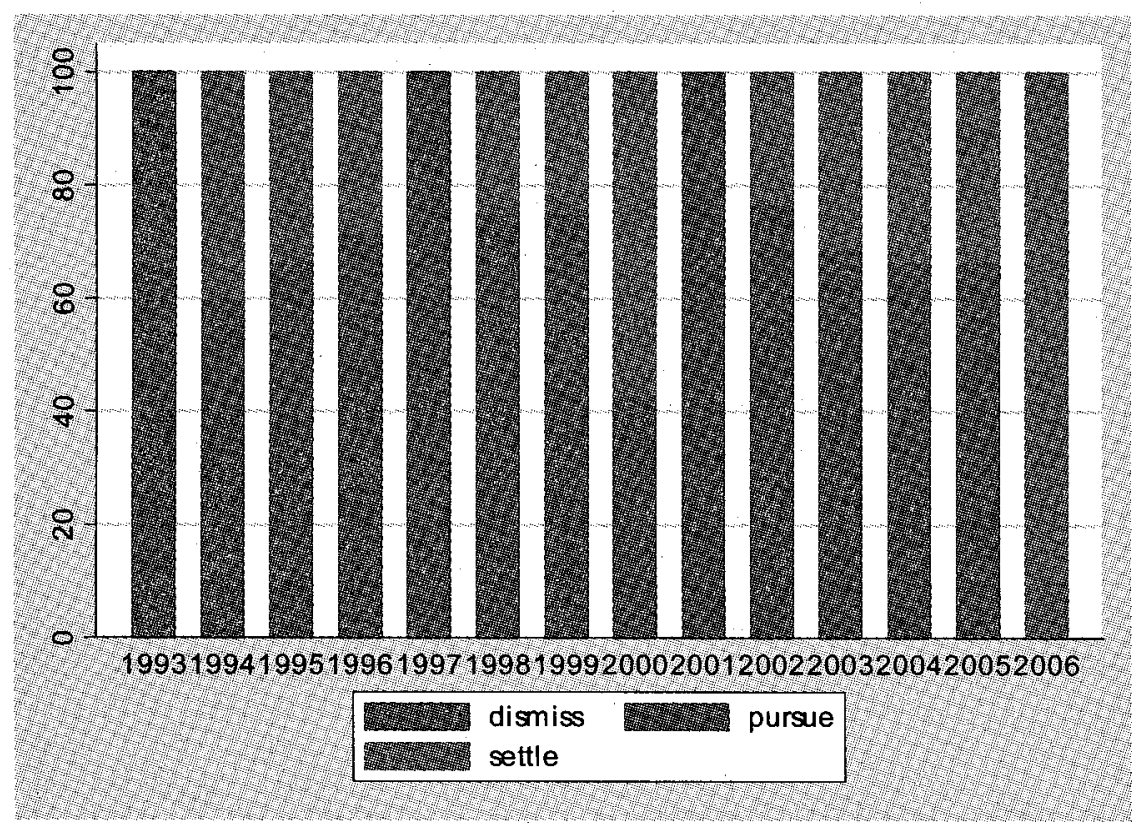

There is a positive correlation $(0.47)$ between year and percentage decisions to settle. There is a negative correlation $(-0.41)$ between year and the percentage of decisions to dismiss and a negative correlation $(-0.11)$ between year and percentage of decisions to pursue. None of the correlations between decision category and year are statistically significant. Thus, the data suggest that decisions to settle are becoming more prevalent, and decisions to pursue and dismiss are becoming less prevalent, but neither trend is statistically significant.

Even if the date range is divided into groups designed to emphasize changes over time, no strong trends appear. The range can be separated into four groups: (1) 199396; (2) 1997-2000; (3) 2001-02; and (4) 2003-06. The second category covers the headier part of the late-1990s technology boom. The third category covers the period following Enron's collapse and the resulting heightened scrutiny of business affairs. The fourth category covers the period following 2003, the year of important Delaware court decisions on SLCs that might have signaled increased scrutiny. ${ }^{48}$ The decisions in

48. See In re Oracle Corp. Derivative Litig., 824 A.2d 917, 947 (Del. Ch. 2003) (denying SLC's motion to terminate proceedings because connections between defendants and SLC members "generate a reasonable doubt about the SLC's impartiality"); Biondi v. Scrushy, 820 A.2d 1148, 1166 (Del. Ch. 2003) (denying SLC's motion to stay proceedings because the conduct of the committee did not indicate it was discharging its responsibilities "with integrity and objectivity"). For commentary on the importance of the cases, see John C. Coffee, Jr.; Gatekeeper Failure and Reform: The Challenge of Fashioning Relevant Reforms, 84 B.U. L. REV. 301, 341 (2004) ("[T] he holdings and dicta in these recent cases have upgraded the level of care and attention that courts are expecting all corporate fiduciaries to exercise. In short, all the 
each category of SLC determination are broken down by chronological group in Table 3.

Table 3. Decisions of SLCs by Groups of Years

\begin{tabular}{|c|c|c|c|c|}
\hline Category of Decision & $\begin{array}{c}1993-96 \\
(\mathrm{n}=20)\end{array}$ & $\begin{array}{c}1997-2000 \\
(\mathrm{n}=24)\end{array}$ & $\begin{array}{c}2001-02 \\
(\mathrm{n}=17)\end{array}$ & $\begin{array}{c}2003-06 \\
(\mathrm{n}=30)\end{array}$ \\
\hline Dismiss & $10(50 \%)$ & $17(71 \%)$ & $12(71 \%)$ & $19(53 \%)$ \\
\hline Settle & $6(30 \%)$ & $7(29 \%)$ & $3(18 \%)$ & $13(36 \%)$ \\
\hline Pursue & $4(20 \%)$ & $0(0 \%)$ & $2(12 \%)$ & $4(11 \%)$ \\
\hline
\end{tabular}

The distribution of decisions over time is not statistically significant $(p=0.27)$. The difference between the two periods that seem least similar, 1993-96 and 1997-2000, is statistically significant at the ten percent level but not at the five percent level $(p=$ 0.059). Although it is hard to see a trend in the data, there are some striking comparisons. Decisions to dismiss represented seventy-one percent of all decisions during each of the two middle periods (1997-2000 and 2001-02), much higher than the same percentage in the period before (fifty percent) or the period after (fifty-three percent). Similarly, there were no SLC decisions to pursue claims during the period from 1997 to 2000 . The most salient difference between $2001-02$ and $2003-06$ is that in the latter period more decisions were to settle and fewer were to dismiss. But because the difference between those periods is not statistically significant $(p=0.35)$, it is difficult to conclude from this evidence that the 2003 Delaware court opinions addressing SLCs had much of an impact on SLC decisions. ${ }^{49}$ Furthermore, although the trend since 1997 appears to be moving away from decisions to dismiss claims and moving toward decisions to settle or pursue them, the similarities between the pre-1997 decisions and the post-2003 cases make it hard to conclude with any confidence that the explanation for the differences between these findings on SLC behavior and the common understanding of such behavior reflect a recent change in SLC behavior. If there was such a change, it predated the EDGAR system.

\section{Bias in Reported Cases}

The 1980 s studies relied on reported court cases. ${ }^{50}$ The limitations of inferences drawn from reported cases are well known. ${ }^{51}$ As Roberta Romano has noted, reported

judicial straws in the wind point towards a higher risk of liability. ..."); Davis, supra note 9, at 1307 ("[T] he recent Oracle decision in Delaware suggests that the courts may be taking a more stringent approach to the SLC in the post-Enron environment.").

49. One prominent Delaware practitioner noted that, "while the independent/not independent line appears to have moved slightly in the latter direction, one cannot conclude that Scrushy and Oracle represent a dramatic change in Delaware's approach to issues of director independence." A. Gilchrist Sparks, III, Andrew H. Lippstone \& Julie R. Windhorn, Trends in the Delaware Corporate Law: Director Liability and Indemnification, in CONTESTS FOR CORPORATE CONTROL: CURRENT OfFENSIVE AND DEFENSIVE STRATEGIES IN M\&A TRANSACTIONS 2004, at 331, 343 (PLI Corp. Law \& Practice Course Handbook Series No. 1405, 2004).

50. Reported cases are rulings issued by courts that resolve some issue of law in dispute and generally involve a written opinion explaining the court's reasoning.

51. E.g., George L. Priest \& Benjamin Klein, The Selection of Disputes for Litigation, $13 \mathrm{~J}$. LEGAL STUD. 1, 2(1984) ("It is well known, however, that only a very small fraction of disputes comes to trial and an even smaller fraction is appealed. In a study of insurance company claims 
cases "are only a fraction of all claims because many claims are settled or dropped prior to trial." 52 Bias might arise because case reports collect only those instances of SLC behavior where an aggrieved party challenges the decision of the SLC and seeks judicial protection. One such scenario is when an SLC moves to dismiss a case and a plaintiff's attorney is cut out of the litigation. Another is when an SLC decides to pursue claims and defendants are placed in peril. ${ }^{53}$ A settlement involving the defendants' and the plaintiffs' attorneys is much less likely to generate a reported case. ${ }^{54}$ Consequently, as others have suggested, inferences about SLC behavior drawn from reported cases might be systematically biased in favor of SLC decisions to dismiss litigation. ${ }^{55}$

Of the ninety-seven SLC decisions taken from EDGAR, twenty-seven are mentioned in reported cases. The aggregate SLC decisions are different from the subset of SLC decisions that appear in reported cases, as Table 4 shows.

Table 4. SLC Determination by Presence in Reported Cases

\begin{tabular}{|l|c|c|c|}
\hline \multicolumn{1}{|c|}{ Category of Decision } & Not in Cases (n=70) & In Cases (n=27) & Total (n=97) \\
\hline Dismiss & $38(54 \%)$ & $20(74 \%)$ & $58(60 \%)$ \\
\hline Pursue & $5(7 \%)$ & $5(19 \%)$ & $10(10 \%)$ \\
\hline Settle & $27(39 \%)$ & $2(7 \%)$ & $29(30 \%)$ \\
\hline
\end{tabular}

As hypothesized, the more contentious SLC decisions are overrepresented in the case reports. When an SLC decides to dismiss the derivative claims, the plaintiff's attorney may challenge the SLC's decision, which could generate a case report. When an SLC decides to pursue the derivative claims, the defendants may challenge the SLC's decision, which could similarly generate a report. The most dramatic difference between the decisions in cases and those not in cases is in SLC decisions to settle. SLC

files, $H$. Laurence Ross reports that, of his sample, only 4.2 percent of claims ultimately reached trial and 0.2 percent of claims were appealed. . . It is very difficult to infer specific characteristics from observations of 0.2 percent or less of a population, especially where there is no evidence that the observations (the disputes selected for appeal) were selected randomly.").

52. ROBERTA ROMANO, FouNDATIONS OF CORPORATE LAW 81 (1993).

53. See Payson et al., supra note 12, at 1207 (noting that if an SLC pursues claims "the individual defendants would probably be in a worse position than if the committee had never been established at all"). An SLC recommendation to pursue claims has produced reported decisions. See Allied Ready Mix Co. ex. rel. Mattingly v. Allen, 994 S.W.2d 4 (Ky. Ct. App. 1998).

54. But see Joy v. North, 692 F.2d 880, 884 (2d Cir. 1982) (stating that SLC recommended settlement with certain defendants); In re Cendant Corp. Derivative Action Litig., 232 F. Supp. 2d 327, 335-36 (D.N.J. 2002) (same); Alford v. Shaw, 358 S.E.2d 323, 324-25 (N.C. 1987) (same).

55. E.g., GeVurTZ, supra note 18 , at $412 \mathrm{n} .106$ ("If the committee finds the suit to be in the corporation's interest, the corporation would have no reason to ask the court to dismiss the suit and the committee's action might not result in a reported court opinion."); KLEIN \& COFFEE, supra note 1, at $207 \mathrm{n} .139$ (noting that Professor Cox's examination of reported cases "may be a biased sample"). Although the ALI draft cited Professor Cox's survey for the proposition that SLCs always dismiss litigation, it cautioned that "decisions to continue or take over the action may not result in reported decisions, and a survey of reported cases may therefore be misleading." AM. LAW INST., supra note 24, at 161. Thus it did "not adopt as its empirical premise" that SLCs "will be invariably hostile" to derivative allegations. Id. at 162. 
decisions to settle rarely appear in the case reports. While SLCs decided to settle approximately thirty percent of the time, only about seven percent of the reported cases involve an SLC decision to settle. The difference between decisions in reported cases and decisions not in reported cases is statistically significant $(p=0.003)$.

It is not surprising that settlements are underrepresented in reported cases. One commentator describes the moment of settlement in the following way: "Plaintiff and defendant(s) join hands to present their agreement to the court for approval. Commonly, there is no opposition." ${ }^{56}$ As Professor Cox noted, "[f]ew settlements ... are rejected" by courts, and published opinions reflecting the process are "isolated." 57 Indeed, the two settlement recommendations in the reported cases appear there only because in each instance there was an objection to some aspect of the settlement. In a settlement involving Cendant Corporation, the plaintiff's attorneys were involved in the settlement, and the reported case arose from a shareholder's objection to the magnitude of the fee award to the plaintiff's attorneys. ${ }^{58}$ The fees were approved. In the other case, which involved TLC Beatrice, the SLC settled directly with a defendant, and the reported case arose from an objection to the settlement by the plaintiff, a substantial shareholder. ${ }^{59}$ The settlement was approved.

\section{E. Case Outcomes}

The percentage of SLC decisions to settle in the data set is high in light of the common understanding of SLC behavior, but it is low when compared to settlement figures in derivative litigation generally. In her study of shareholder litigation, Professor Romano found that approximately sixty-five percent of derivative suits resulted in a settlement, a conclusion she characterized as unremarkable because most civil suits settle. ${ }^{60}$ When all procedural developments following the SLC decisions are taken into account, cases subject to SLC authority ended up looking like derivative litigation generally: Approximately seventy percent of the time they ended in settlement.

\section{SLC Decisions to Dismiss}

Of the fifty-eight instances where a committee decided that the claims should be dismissed, it was possible to determine what events followed in fifty-three. When an SLC decided the claims should be dismissed, a court ruled on the motion in thirty-two instances (sixty percent). There was an intervening settlement prior to a court ruling in

56. GEVURTZ, supra note 18 , at $\mathbf{4 3 5}$ (alteration in original). A drawback of the settlement motive, in Professor Gevurtz's view, is that "the lack of opposition seriously undercuts the ability of judicial approval to protect the corporation from poor settlements." Id.

57. James D. Cox, The Social Meaning of Shareholder Suits, 65 BroOK. L. REV. 3, 12 (1999).

58. In re Cendant Corp., 232 F. Supp. $2 \mathrm{~d}$ at 331.

59. Carlton Invs. v. TLC Beatrice Int'l Holdings, Inc., No. 13950, 1997 WL 305829 (Del. Ch. May 30, 1997).

60. Roberta Romano, The Shareholder Suit: Litigation Without Foundation?, 7 J.L. EcoN. \& ORG. 55, 60 (1991) ("Most lawsuits (83 of 128 resolved suits) settled. This aspect of shareholder litigation is unremarkable; most civil suits settle."). 
sixteen instances (thirty percent); the filings note occasionally that the SLC is involved in these subsequent settlements, though that is not common. ${ }^{61}$

Of the thirty-two court decisions on SLC motions, twenty times (sixty-two percent of court decisions) the SLC's motion was granted entirely. Out of those twenty court rulings granting the SLC's motion, seventeen times the underlying cases were ultimately dismissed and all appeals failed. Three times following a grant of an SLC motion the underlying cases settled, presumably to foreclose any appellate review.

A court partially granted the SLC's motion to dismiss twice (six percent of court decisions). In each instance, the cases settled following the court's ruling.

The SLC's motion to dismiss was denied ten times (thirty-one percent of court rulings). In two of the ten denials, filings noted that the ruling was based on a lack of independence. ${ }^{62}$ When the SLC's motion was denied, the underlying cases settled seventy percent of the time (seven out of ten denials). Following denial, one filer entered bankruptcy. One denial was reversed on appeal by the Pennsylvania Supreme Court, ${ }^{63}$ and on remand the case was dismissed. Following denial, one suit in Delaware against managers of Oracle Corporation was ultimately resolved by summary judgment for the defendants. ${ }^{64}$

The final outcomes when an SLC decides to dismiss are shown in Table 5.

Table 5. Final Outcomes When the SLC Decided to Dismiss

\begin{tabular}{|l|c|}
\hline \multicolumn{1}{|c|}{ Outcome } & Frequency $(\mathrm{n}=53)$ \\
\hline Settlement & $28(53 \%)$ \\
\hline Dismissal & $18(34 \%)$ \\
\hline Withdrawal of derivative claims & $2(4 \%)$ \\
\hline Intervening bankruptcy & $3(6 \%)$ \\
\hline Amended complaint with new claims; older claims ignored & $1(2 \%)$ \\
\hline Summary judgment for defendants & $1(2 \%)$ \\
\hline
\end{tabular}

\section{SLC Decisions to Settle}

Of the twenty-nine instances where the SLC decided to settle the claims, twentyeight of them (ninety-seven percent) came to fruition as a final settlement. In one instance, the settlement fell apart, and it was not possible to determine what happened in the underlying derivative claims.

61. The other outcomes at this stage were as follows: twice following the SLC's decision to dismiss the filer went into bankruptcy (four percent), and twice the plaintiffs withdrew their derivative claims (four percent). In one instance, the plaintiffs filed an amended complaint that ignored the earlier and less potent allegations investigated by the SLC (two percent).

62. Perhaps more rulings were based on a lack of independence, but the grounds for denial are not reliably disclosed.

63. Cuker v. Mikalauskas, 692 A.2d 1042 (Pa.1997).

64. In re Oracle Corp., 867 A.2d 904, 906 (Del. Ch. 2004) (granting summary judgment to remaining defendants). Oracle's derivative claims brought in another state were settled. 


\section{SLC Decisions to Pursue}

When SLCs decided to pursue claims, they succeeded. All ten instances in which an SLC decided to pursue claims ended partially or entirely with a settlement with or judgment against the defendants.

In eight of those instances, the SLC moved to dismiss the claims it was not pursuing. Two of those cases settled before the court ruled on the motion. In the remaining six cases, the motions for partial dismissal were granted.

The two instances that have not been consummated in a complete settlement are as follows: One company's claims against a former CEO are still outstanding; its claims against other executives in that case have been settled. In another instance, the company went to trial against two former executives and won. One former executive settled following judgment for the company, and the other is currently appealing the judgment pro se.

\section{Combined Outcomes}

Table 6 shows the aggregated outcomes of cases subject to SLC authority.

Table 6. Aggregated Outcomes of Claims Subject to SLCs

\begin{tabular}{|l|c|}
\hline \multicolumn{1}{|c|}{ Outcome } & Frequency (n=92) \\
\hline Settlement & $64(70 \%)$ \\
\hline Dismissal & $18(20 \%)$ \\
\hline Plaintiff's claims dropped altogether & $2(2 \%)$ \\
\hline Summary judgment for defendants & $1(1 \%)$ \\
\hline One claim outstanding, others settled & $1(1 \%)$ \\
\hline Judgment against some defendants; others settled & $1(1 \%)$ \\
\hline Amended complaint based on new facts & $1(1 \%)$ \\
\hline Unknown outcome & $4(4 \%)$ \\
\hline
\end{tabular}

As shown earlier in this Section, SLCs dismiss cases less frequently than is commonly thought. This data shows that the underlying cases end in dismissal far less frequently than is commonly thought. ${ }^{65}$

To be sure, dismissal occurs twenty percent of the time. Professors Macey and Miller have suggested that the claims pressed by plaintiffs' attorneys in the face of an SLC generally are meritorious, ${ }^{66}$ but it is difficult to conclude that the dismissal rate of twenty percent is in any respect a high figure in view of other evidence adduced on the

65. For example, Professors Thompson and Thomas, relying on what they concede are "limited data," note support for the view that "the appointment of a special litigation committee almost always leads to the dismissal of the case." Thompson \& Thomas, supra note 18, at 1791 n. 147.

66. See Jonathan R. Macey \& Geoffrey P. Miller, The Plaintifs' Attorney's Role in Class Action and Derivative Litigation: Economic Analysis and Recommendations for Reform, $58 \mathrm{U}$. CHI. L. REv. 1, 40-41 (1991) ("[B]y prosecuting the litigation, the plaintiffs' attorney demonstrates in a highly reliable way that the suit has favorable prospects for generating value for the corporation. The fact pattem suggests a probability that the litigation is indeed in the corporation's best interest."). 
merits of derivative (and other shareholder) litigation. ${ }^{67}$ The predominance of settlement is not in the end very surprising. ${ }^{68}$ As noted, most cases, derivative and otherwise, settle. Indeed, the claims involved in Zapata Corp. v. Maldonado, ${ }^{69}$ the same claims that led to the landmark Delaware case on the appropriate level of judicial scrutiny for SLC decisions, ${ }^{70}$ settled on the eve of trial. ${ }^{71}$

\section{F. Settlement Recoveries}

The data reported here demonstrate that the claim about SLC decisions-that they always move to dismiss shareholder litigation-is no longer accurate. SLC decisions to pursue or settle claims, however, might be only formally adverse to the defendants. The widespread claim that SLCs always dismiss might thus be inaccurate only in the most technical sense. When SLCs seek to pursue or settle claims, they may fail to press them in any serious way, thus achieving the same result as if the claims had been dismissed. Even if SLCs do not invariably dismiss claims against defendants, they may take it especially easy on them.

The settlement data shows that SLCs did not take it easy when settling or pursuing claims. Instead, they recovered meaningful amounts for the company. When SLCs decided to pursue claims, the median recovery as a percentage of firm value was $0.75 \%$, and when SLCs decided to settle claims, the median recovery was $0.25 \%$. The median recovery in settlements in cases where SLCs decided to dismiss claims was zero in the median instance. Figure 3 shows box plots of recoveries (excluding outliers) to the company as a percentage of firm value for each settlement stage.

67. Stephen P. Ferris, Tomas Jandik, Robert M. Lawless \& Anil M. Makhija, Derivative Lawsuits as a Corporate Governance Mechanism: Empirical Evidence on Board Changes Surrounding Filings, 42 J. Fin. \& QuaNTITATIVE ANALYSIS 143, $159-62$ (2007) (finding significant governance improvements following derivative suits that managers lose); Romano, supra note 60, at 61 ("[A] significant proportion of shareholder suits are without merit."); Robert B. Thompson \& Randall S. Thomas, The New Look of Shareholder Litigation: Acquisition-Oriented Class Actions, 57 VAND. L. REV. 133, 138, 141 (2004) (noting that acquisition-oriented shareholder litigation suits "have many of the same characteristics identified in securities fraud and derivative cases as indicators of litigation agency costs" but noting that they remain a "valuable tool to check managerial agency costs"); Thompson \& Thomas, supra note 18, at 1750 (noting that "the claim that derivative suits are typically strike suits is much weaker than in earlier periods").

68. E.g., Macey \& Miller, supra note 66, at 44 ("Most ... derivative litigation is settled prior to judgment. When such litigation is settled, the problem of agency costs appears in a particularly problematic form. As already discussed, the plaintiffs' attorney often faces a severe conflict of interest in settling class and derivative litigation."); Joel Seligman, The Disinterested Person: An Alternative Approach to Shareholder Derivative Litigation, 55 LAW \& CONTEMP. PrOBS. 357, 361 (1992) (noting that shareholder litigation "is part of a litigation process that more often than not results in settlements").

69. 430 A.2d 779, 787 (Del. 1981).

70. See supra text accompanying note 30 .

71. Maher v. Zapata Corp., 714 F.2d 436, 448 (5th Cir. 1983). 
Figure 3. Company Financial Recovery Expressed as a Percentage of Firm Value by SLC Decision and Court Decision Within SLC Decisions to Dismiss

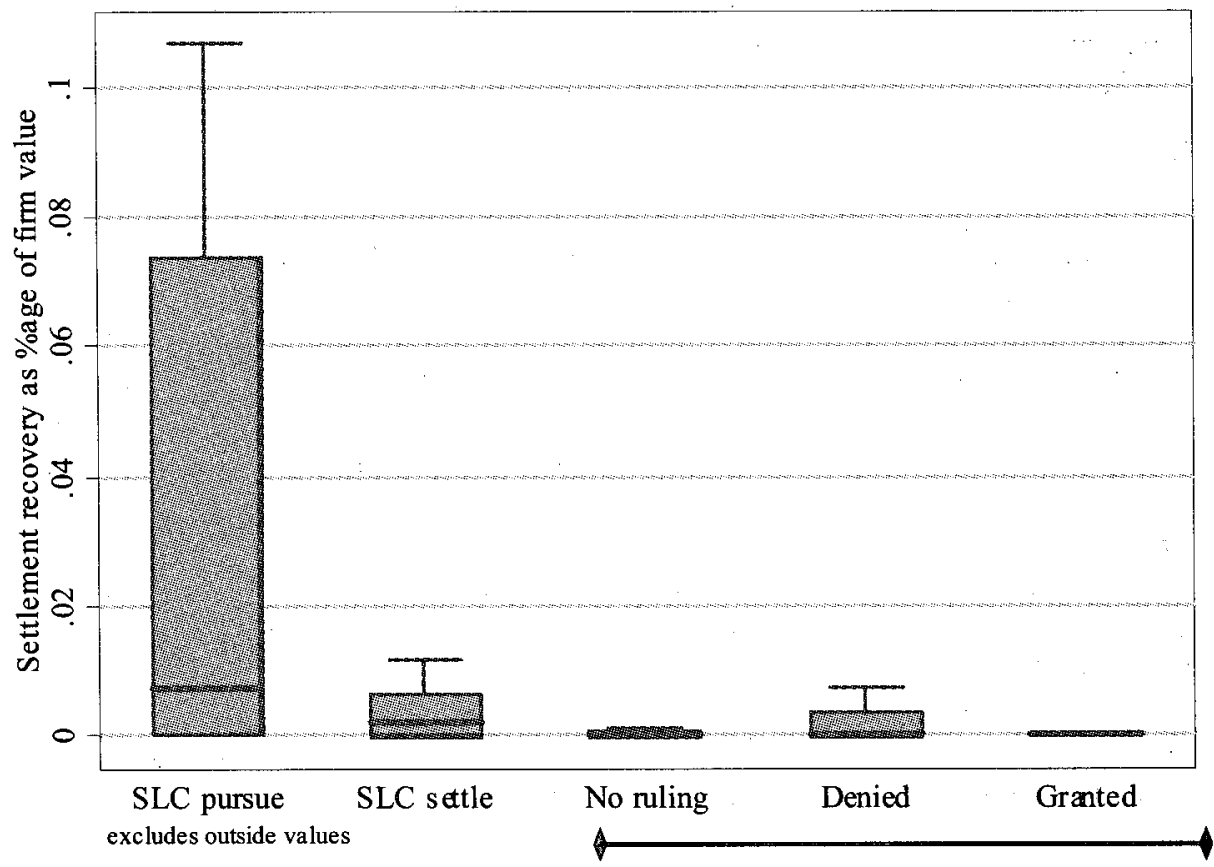

The amounts recovered by companies when SLCs decided to settle claims or pursue them suggest that the SLCs were not attempting to exculpate the defendants with their decisions. As noted, the median recovery as a percentage of firm value was $0.75 \%$ when SLCs decided to pursue claims. This includes one company that has not yet resolved all of its outstanding claims, and if that company's recovery is excluded, the median recovery was $1.4 \%$ as a percentage of firm value when SLCs decided to pursue claims. In addition to the financial recovery, SLC decisions to pursue also resulted in structural relief. The most notable of this sort of relief involved Dart Group, Inc. In that settlement, the defendant controlling shareholders relinquished their control and the company dismantled its dual-class stock structure. When SLCs decided to settle claims, the median recovery was lower but nonzero: $0.25 \%$ as a percentage of firm value. SLC settlements also included important structural relief in some cases. In one, for example, a company agreed to give the plaintiff control over two board seats, repeal various shark repellents, and cancel certain loans to directors.

These settlement recovery data show that SLC decisions to dismiss and to settle claims were not attempts to achieve dismissal for the defendants by another name. It could still be the case, of course, that SLCs systematically treat defendants more leniently than would shareholder-plaintiffs. There is no control group here of shareholder-pursued derivative claims without SLCs, so there is no easy comparison.

SLCs might treat defendants more mildly for at least two reasons. First, they might afford defendants more lenient treatment because they take factors into consideration that shareholder-plaintiffs do not, like the extent to which pressing a claim might distract management from business operations or strain the relationship between the company and management. The incentive a plaintiff's attorney has to pursue a claim is 
solely a function of the attorney fee available, which is usually tied to the financial benefit to the corporation. The SLC might be as mindful of the harms avoided by refraining from pressing the claims as of any benefits conferred by pressing them.

The second reason that an SLC might be easier on defendants is the familiar account of structural bias. On this account, the members of the SLC are guided by a concern for the well-being of their executive colleagues. This may drive SLCs to attempt to keep any settlements within the policy limits of the applicable director and officer insurance plan, so as to avoid placing any personal liability on executives. The results here suggest that if structural bias does partly explain what SLCs do, it operates in a much more bounded way. Any effect structural bias has is at the margins.

\section{G. How the Merits Relate to SLC Decisions}

These data also offer some insight into how SLC decisions may be related to the merits of the underlying shareholder claims. Figure 3 shows that financial recoveries to the company are high when SLCs pursue, very low when SLCs dismiss, and in between when SLCs settle. If the settlement values are a function of the merit of the claims, SLCs thus appear to make their decisions based on the underlying merits. They pursue strong claims, dismiss weak ones, and settle close ones.

Settlement values, however, might be a function not of merit but of the procedural posture at the time of settlement. Directors may ignore the merits of a claim, deciding whether to pursue, settle, or dismiss it based on how friendly they are with the defendant or some other criterion. The ultimate settlement value is a function only of the procedural obstacles facing the claim at settlement. On this account, the low settlement values in cases where an SLC decided to dismiss the claims are evidence not of meritless claims but of the overwhelming procedural obstacles they face. Similarly, the high amounts recovered when SLCs pursued claims may be evidence not of the strength of the claims but of the unstoppable inertia in favor of a finding of defendant liability. If settlement values are unrelated to the underlying merit and are just a reflection of the claim's procedural posture at settlement, ${ }^{72}$ then these data demonstrate that the SLC's effect on the procedural posture of the case is dramatic.

\section{H. Time to Resolution}

Why might a company appoint an SLC, if not to dismiss claims? These data suggest a potential explanation that has been thus far overlooked. The average duration from the first filing of the claim to the final resolution of claims is 2.3 years. ${ }^{73}$ This is almost twice as fast as the standard duration of shareholder derivative litigation. ${ }^{74}$ Some claims were resolved the same year they were filed, and the longest duration from filing to resolution was twelve years. Breaking the mean durations down by category of

72. E.g., BAINBRIDGE, supra note 7, at 403 ("A substantial percentage of derivative litigation likely consists of strike suits, which are settled for their nuisance value.").

73. This excludes appeals of dismissal orders, unless the ultimate resolution is a settlement during the appeal process.

74. In her earlier study of shareholder suits, Romano found that the average duration of a shareholder suit was four years. See Romano, supra note 60 , at $74 \mathrm{n} .32$. While not a perfect comparison, her study is the best source for this kind of data on derivative litigation. 
SLC decision shows that claims SLCs determined to settle were resolved faster $(1.8$ years) than claims SLCs decided to pursue ( 2.5 years) or dismiss ( 2.5 years). Focusing only on the mean total durations understates the effect of the SLC decision to settle on the speed with which claims are resolved. Figure 4 shows for each category of SLC decision the mean time of the SLC decision and the mean time of final resolution of the claims, plotted from the date of filing.

Figure 4. Time of SLC Decisions and Final Resolutions by SLC Decision and the Date of Filing

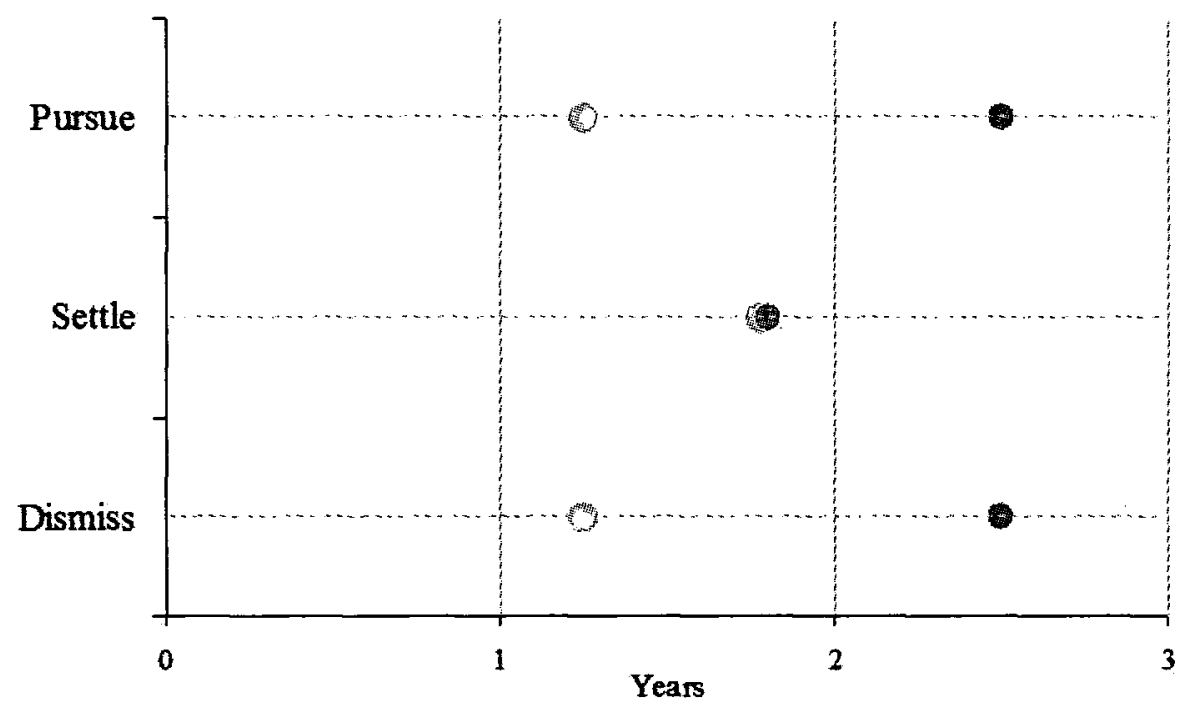

OSLC Decision Final Resolution

SLC decisions to settle resulted in resolution of the claims almost immediately. By contrast, when SLCs decided to pursue or dismiss claims, those claims were not resolved for another 1.2 years in decisions to dismiss and 1.3 years in decisions to pursue. SLC decisions to settle thus were usually made longer after the filing of claims than either decisions to pursue or dismiss, possibly a consequence of the time needed to negotiate the settlement. But once the SLC decided to settle, the cases were resolved almost immediately. Dismissing claims was not easy; on average, it took nearly as long to have a claim dismissed as to pursue it. Settlement provided a much faster resolution of the claims than either trying to have the claims dismissed or pursuing them.

The short aggregate time from filing to final resolution and the rapidity with which SLC decisions to settle resolved claims suggest that the appointment of an SLC might not be designed to result in dismissal of the claims but instead to result in their speedy resolution. On this view, the SLC process is a form of alternative dispute resolution. ${ }^{75}$

75. See Daniel S. Kleinberger \& Imanta Bergmanis, Direct vs. Derivative, or "What's a Lawsuit Between Friends in an 'Incorporated Partnership? '", 22 WM. MrTCHELL L. REV. 1203, 1235 (1996) ("[S]pecial litigation committees are a form of alternative dispute resolution. They sift facts and make recommendations in the shadow or context of litigation proceedings, but they do not directly consume court resources and are not laden with all the procedural paraphernalia 
A company may appoint an SLC because doing so resolves claims faster and cheaper than the standard course of civil derivative litigation. Appointing an SLC may save on the costs of defense, but that is generally covered by insurance in any case; another important source of savings might be from conserving management attention, the loss of which cannot be compensated by insurance. An SLC might find that pursuing claims in court is worth the extra expense only when the claims are especially meritorious, and seeking the dismissal of claims may be worth the expense only if the claims are especially meritless. But for claims not worth pursuing but too meritorious to dismiss, an SLC settlement may offer the fastest and cheapest way to resolve the claims.

The structure of director and officer insurance may play a role in causing the appointment of an SLC to increase the incentive for the plaintiffs and their attorneys to settle. As Tom Baker and Sean J. Griffith have shown, the costs of a corporation's defense can diminish the total amount available to plaintiffs in settlement. ${ }^{76}$ If the appointment of an SLC causes the corporation to increase its litigation defense costs, this may induce plaintiffs to settle faster.

\section{CONCLUSION}

Contrary to the predominant view in legal scholarship, SLCs do not invariably move to dismiss litigation. Instead, approximately forty percent of the time SLCs either settled claims or pursued them against one or more defendants. These decisions to pursue or settle claims resulted in substantial financial recoveries for the corporation, indicating that SLCs are not taking it easy on defendants. In view of the speed with which claims subject to SLC authority are resolved, the SLC appears to function as a form of alternative dispute resolution.

The claim that directors uniformly side with their colleagues in derivative litigation has underwritten suspicion of independent and disinterested directors in all areas where corporate law calls on them to police conflicts of interest. Although this Article does not demonstrate that independent and disinterested directors can be uniformly trusted to monitor conflicts in derivative litigation or elsewhere, it should unsettle blanket claims - based on their decisions during derivative litigation — of bias in their behavior.

\section{APPENDIX}

Special litigation committees were identified by running word searches through the SEC's EDGAR database during the ten-year period from 1995 to $2004 .^{77}$ All variables used in this paper were gathered from company filings and have not been supplemented with data collected from other sources. The word searches used cover the standard judicial and academic description and also various alternative

of litigation.").

76. See Tom Baker \& Sean J. Griffith, How the Merits Matter: Directors' and Officers' Insurance and Securities Settlements, 157 U. PA. L. REv. 755, 777-78 (2009) ("Assuming that the claim will settle within insurance limits, this means that increasing defense costs also decreases the total pot available to plaintiffs in settlement.").

77. The EDGAR database is the SEC's repository for electronic company filings. See U.S. Sec. and Exch. Comm.: Filings \& Forms, http://www.sec.gov/edgar.shtml. Some filings during that period describe SLC behavior from before that period and after it, and that data has been included in this study. 
formulations: "litigation committee"; "special committee" <near/25> (derivative or derivatively or "shareholder litigation"); "investigation committee"; "investigative committee"; "investigatory committee"; (disinterested or outside) $<$ near $/ 20>$ committee $<$ near/25> (litigation or lawsuit or allegations or claims); ("independent committee" or "independent directors") $<$ near/25> (litigation or lawsuit or allegations or claims).

When the SEC adopted its electronic filing requirements, it divided the filers into groups and phased them into the system by group. ${ }^{78}$ That process started in April 1993 and ended on May $6,1996 .{ }^{79}$ Since that date, all filers have been required to file electronic copies for the EDGAR database absent a showing of hardship. ${ }^{80}$ The beginning of the time restriction in the EDGAR searches here was January 1, 1995, but it was not until May 6, 1996 that the SEC completed its phase-in of all registrants into EDGAR, and thus the number of SLCs in the early part of the data likely does not capture all SLC activity among SEC filers during those years. There is no reason to believe that SLC decisions in EDGAR from January 1995 to May 1996, however, are biased in favor of any particular SLC behavior. ${ }^{81}$

Each filing that appeared in the search results was reviewed to determine whether the registrant (or a related company) had formed an SLC. For purposes of this study, an SLC is a board committee with authority over pending derivative litigation. Determining whether a committee had the authority over derivative litigation was sometimes tricky. Indications of a committee's authority came from the language describing the committee's review, any requests for a stay of proceedings during the investigation, descriptions of the board's delegation, any indication that the Company (as opposed to defendants) moved for dismissal, and sometimes the committee's name (for example, "Shareholder Derivative Claim Review Committee").

For any committee called a "special litigation committee," the default treatment was that it had power sufficient to be included in this study. However, if the responsibilities disclosed for such committee were limited to some purpose other than overseeing shareholder derivative litigation (for example, to address a shareholder demand or to manage securities litigation), then it was excluded. One important exception here is a committee formed in response to a demand letter where the substantive allegations of the demand letter are identical to pending derivative litigation and the committee determines to reject the demand and also, for example, moves to dismiss the pending litigation. Such a committee would be included.

If the disclosure documents offered no indication of the committee's powers or purpose, the committee was included only if there was pending derivative litigation disclosed, developments in the litigation that were not otherwise explained, and no equally plausible alternative explanations for the work of the committee were available. A few circumstances warrant special mention. Committees formed to oversee an internal investigation of matters that attracted derivative litigation subsequent to the

78. Rulemaking for EDGAR System, Exchange Act Release No. 33-7122, 59 Fed. Reg. 67,752 (Dec. 30, 1994).

79. Charnas \& Nordlund, supra note 40 , at 286 ("This phase-in was completed by May 6 , 1996, and all registrants should currently be using EDGAR for their filings.").

80. See Regulation S-T, 17 C.F.R. $§ 232.100$ (2008).

81. No available source indicates how companies were chosen to be phased into EDGAR, but there is no reason to believe that it was done in a way that would introduce bias into the inquiry here. 
creation of the committee are included only if the committee's authority explicitly addresses litigation. Also, committees formed to "advise" a board on derivative litigation were not included. ${ }^{82}$

The overwhelming majority of the search results were false positives. Many of the search results were included only because responsive words were near each other without any substantive relevance. Also, the term "special litigation committee" is commonly mentioned in company by-laws filed with registration statements. Additional nonresponsive uses of the term in the results included the following: to oversee securities litigation (simply as division of labor on the board) or investigations; in the discussion of a director's qualifications (e.g., a lawyer serves on her law firm's litigation committee, worked on an ABA litigation committee, etc.); in a description of other events (e.g., company settled claims by executing memorandum of understanding with plaintiff's "litigation committee"); to evaluate a demand made upon the board; in a description of merger party's SLC; in a description of rights under Delaware law in reincorporation proxy materials; to monitor conflicts between a fund advisor and a fund regarding litigation relating to securities held by both fund and advisor; or to oversee litigation when other board members have a conflict of interest (e.g., redeem certain securities and some board members may own some of those securities).

One concern with using EDGAR as a source for data is that SEC regulations are unclear about the extent to which derivative litigation must be disclosed, and nothing requires the disclosure of an SLC's existence or behavior.

On the disclosure of derivative litigation, Item 103 of Regulation S-K requires that a company "[d]escribe briefly" all "material legal proceedings" to which it is a party. ${ }^{83}$ The instructions to Item 103 make clear that it applies to "[a]ny material legal proceeding[]" where "any director, officer or affiliate of the registrant ... is a party... [and where the proceeding] has a material interest adverse to the registrant or any of its subsidiaries." ${ }^{, 84}$ A prominent commentator has suggested that this instruction is aimed at derivative litigation. ${ }^{85}$

On the disclosure of the existence of an SLC, the regulations are silent and cases point in both directions. ${ }^{86}$ An additional ambiguity with disclosure of derivative claims

82. See Grimes v. Donald, 673 A.2d 1207, $1216 \mathrm{n} .13$ (Del. 1996) ("The use of a committee of the board formed to respond to a demand or to advise the board on its duty in responding to a demand is not the same as the SLC process.").

83. 17 C.F.R. $\S 229.103$ (2008).

84. Id. (Instruction No. 4).

85. See Joel Seligman, The SEC's Unfinished Soft Information Revolution, 63 FORDHAM L. REV. 1953, 1964 (1995) (citing Instruction No. 4 for the proposition that "[t]he instructions to Item 103 provide some guidance concerning ... derivative litigation. ...").

86. See 17 C.F.R. $\$ 229.103$ (not addressing SLCs). Compare Bradshaw v. Jenkins, No. C38-771R, 1984 WL 2405 (W.D. Wash. Mar. 9, 1984) (suggesting that an SEC registrant had a duty to disclose the creation of an SLC to consider a shareholder demand), with In re BrowningFerris Indus., Inc. S'holder Litig., 830 F. Supp. 361, 368 (S.D. Tex. 1993) (holding that the omission of unsubstantiated claims of director wrongdoing in a demand letter or the existence of a special committee investigating allegations in a demand letter cannot support a proxy violation claim), and Bell Atl. Corp. v. Bolger, 771 F. Supp. 686, 687 (E.D. Pa. 1991) (suggesting that a corporation had no duty to disclose an SLC's existence or its conclusion not to pursue litigation because the omission was not "so obviously important to an investor, that reasonable minds cannot differ on the question of materiality"), and Bolger v. First State Fin. Servs., 759 F. Supp. 
arises from the requirement that the registrant's interest be "adverse" to that of the director, officer, or affiliate. Although derivative claims are made in the name of a corporation and any recovery accrues to the corporation, not the shareholder plaintiff, the corporation is often named in the complaint as a nominal defendant along with the other defendants. This might preclude a finding that the parties were adverse, as one court has concluded. ${ }^{87}$ Consequently, disclosure of the derivative suit and presumably any related committee investigations would not be required.

The actual disclosure practice of SEC filers, however, shows that they disclose information about derivative litigation and SLCs in their filings. This was uncovered by looking at the disclosure practices of companies with SLCs appearing in reported cases. Running Westlaw word searches through all federal and state cases between 1995 and 2007 revealed thirty-one organizations with SLCs that (1) reported to the SEC and had been phased-in to EDGAR and (2) would have disclosed the existence of the SLC within the date search range (1/1/1995 to 12/31/2004). Of those thirty-one organizations identified in the cases, twenty-six (eighty-four percent) of them disclosed information in their SEC filings sufficient for the existence of their SLC to be identified independent of the case searching. Of the remaining five organizations, two disclosed the existence of the underlying derivative litigation but not of the SLC. The remaining three did not disclose either the derivative litigation or the SLC's existence, although one of those three was a group of mutual funds not subject to Regulation S-K. This finding offers a measure of confidence that SEC registrants are in the habit of disclosing the existence of SLCs and underlying derivative litigation.

To see how effectively the EDGAR searching protocol was at identifying companies with SLCs, the EDGAR results were compared to the list of twenty-six companies with SLCs appearing in reported cases that actually disclosed the existence of the SLC within the date search range (1/1/1995 to 12/31/2004). All twenty-six of them had been identified independently with the EDGAR searching.

Each committee's decision on the pending derivative litigation was identified. Sometimes the committee's conclusion was explicitly stated in the disclosure documents. Sometimes it was inferred based on developments in the litigation. An example inference would be a company where the existence of an SLC is noted in proxy materials, and the periodic filings during the same period disclose pending derivative litigation. If the proxy materials note that the committee was disbanded in a particular year and contemporaneously the periodic filings indicate that the company (as opposed to the defendants) had moved for dismissal, that development was coded as an SLC decision to dismiss.

Decisions to settle merit special mention. Company filings sometimes disclosed explicitly that a committee had determined to settle claims, but oftentimes there was no such disclosure; a filing might simply indicate that a case had settled. Consequently, these are the instances where the most inferences of behavior were drawn (as opposed to finding an explicit disclosure of a decision to settle). For example, if a company's filing in one quarter noted that it had appointed an SLC to investigate a derivative

182, 192-98 (D.N.J. 1991) (holding that omission of existence of SLC investigating derivative claims cannot support a proxy violation claim).

87. See In re Sears, Roebuck and Co. Sec. Litig., 792 F. Supp. 977, 982 (E.D. Pa. 1992) (finding in a claim involving an omission by Sears, Roebuck and Co. of derivative litigation against directors that the "directors were not parties 'adverse' to Sears in any respect" because "Sears was a nominal defendant ... and the directors were also defendants."). 
claim and the proceedings were stayed during the committee's investigation, and the following quarterly report indicated that the derivative claims ended in a settlement, that was coded as an SLC decision to settle. The filings do not generally disclose whether the SLC initiated the settlement. Perhaps it did, or perhaps the shareholderplaintiff and the defendants agreed to the settlement themselves and presented the agreement to the SLC. But even if the SLC does not initiate the settlement, it certainly need not acquiesce to one if it has the board's full authority over the claim. If the SLC decisions to settle are divided into the group of explicit decisions and inferred decisions, there are no statistically significant differences in the recoveries. Further, if the decisions to settle cannot be attributed to the SLCs, then they must be attributed to the defendants, suggesting that defendants were unwilling to take a chance on the accuracy of the claim that SLCs always decide to dismiss claims. Further research involving court filings will resolve whether SLCs were involved in these particular settlement decisions. 